\title{
Africa's Leadership Challenges in the 21st Century: What Can Leaders Learn from Africa's Pre-Colonial Leadership and Governance?
}

\author{
Japhace Poncian ${ }^{1} \&$ Edward S. Mgaya ${ }^{1}$ \\ ${ }^{1}$ Faculty of Humanities and Social Sciences, Mkwawa University College of Education, Iringa, Tanzania. \\ Correspondence: Japhace Poncian, Faculty of Humanities and Social Sciences, Mkwawa University College of \\ Education, P. O. Box 2513, Iringa, Tanzania. E-mail: jponcian@muce.ac.tz; jponcian@yahoo.co.uk
}

Received: March 10, 2015

Accepted: March 30, 2015

Available online: April 9, 2015

doi:10.11114/ijsss.v3i3.710

URL: http://dx.doi.org/10.11114/ijsss.v3i3.710

\begin{abstract}
Africa continues to face serious development challenges despite recent record growth rates. Such challenges as dependency, corruption, underdeveloped infrastructure and production sectors, and leadership and governance are some of the impediments to Africa's quest for sustainable and equitable development. Explaining such development challenges has continued to elude scholars. To the radical leftist scholars, Africa's underdevelopment can adequately be explained by its forceful and uneven integration into the global economic system. However, with over fifty years of independence, the debate is increasingly focusing on Africa's leadership as good explanation for its poverty and underdevelopment. This paper argues that the current poverty and underdevelopment of Africa have much to do with enabling conditions created by African leaders and proposes that addressing this requires Africans to go back to pre-colonial history where they can tap good lessons rather than continuing importing Western based models which may not necessarily fit into Africa's unique characteristics.
\end{abstract}

Keywords: leadership; governance; Africa; pre-colonial

\section{Introduction}

The question of leadership has acquired centre stage in many of the writings about Africa's development challenges. There is a good body of knowledge that associates Africa's underdevelopment with its poor leadership (see for example, Mbah, 2013; Afegbua \& Adejuwon, 2012; Mills, 2011; Mills, 2010; Heleta, 2007). Many of these writings have held African leaders responsible for much of the continent's economic, political and social woes. According to Greg Mills, Africa's poverty is not because of the lack of capital, access to world markets, technical experts, or the unfair global economic system, it is rather because African leaders have made poor choices and decided to keep the continenent in abject poverty (Mills, 2011; Mills, 2010). This observation is shared by Mbah who argues that the 'fundamental cause of African underdevelopment and conflicts lies in the vicious leadership in the continent from 1960s' (Mbah, 2013: $\mathrm{p}$. 142).

Such an approach has also informed much of the development programmes in the continent. Most importantly has been the quest to get leadership right for any meaningful development to take place in the continent. Governance reforms adopted in the 1990s have focused on getting institutions and leadership right because it is believed leadership is central to the attainment of any reform objectives (Kauzya \& Balogun, 2005). African countries themselves have come to the realisation that nothing can be achieved if the poor leadership syndrome is not addressed. For example, some past and present African leaders have taken on the challenge and

established the African Leadership Council, promulgated a Code of African Leadership with 23 commandments, issued a Mombasa Declaration promoting better leadership, and proposed a series of courses to train their political successors in the art of good government (Rotberg, 2004: para. 10).

While much on this line has been done to address the challenge, little attention has been paid on the role that Africa's past leadership and governance systems can play and what lessons can be learnt from them to address the $21^{\text {st }}$ Century challenges. Although Africa's $21^{\text {st }}$ century leadership challenges are too complex and multifaceted to be resolved by learning from pre-colonial leadership successes, this paper sets out to make an argument that there is a lot that Africa can learn from its pre-colonial leaders and leadership systems. The paper is organised as follows: section two examines how leaders have failed Africa's development initiatives followed by an examination of how Africa and the global 
society have responded to the continent's leadership challenges. This is followed by an examination of how pre-colonial leaders and leadership systems can be of relevance to $21^{\text {st }}$ century Africa. Finally, concluding remarks are given.

\section{Africa's development challenges: how leaders have failed Africa}

Africa's development challenges and its marginal role in the international political economy have generated heated and continued debate for quite some time now. To the likes of Walter Rodney (1973), Kwame Nkrumah (1965), Patrick Bond (2006) and Samir Amin $(2014,2011,1977)$, Africa's underdevelopment is to be explained by its colonial and post-colonial capitalist and imperialist economic exploitation and marginalisation. Africa's poverty and underdevelopment can therefore be explained by the way it has been integrated into the global system since the mercantile era (Amin, 2014). Patrick Bond sums up the root of Africa's poverty and underdevelopment thus,

Africa is poor, ultimately, because its economy and society have been ravaged by international capital as well as by local elites who are often propped up by foreign powers. The public and private sectors have worked together to drain the continent of resources which otherwise- if harnessed and shared fairly- should meet the needs of the peoples of Africa... (Bond, 2006: p. 1).

To others like George Ayittey (1999, 1992), Greg Mills (2011) and Robert Calderisi (2007) Africa's underdevelopment can be explained by the internal arrangements and weaknesses within Africa itself. Within this second group of scholars who ascribe to internal causes of Africa's underdevelopment, there is a growing body of knowledge associating underdevelopment with Africa's bad leadership. According to Mills (2011, 2010), Africa is poor today mainly because its leaders have chosen poverty over development of its people. Bad leadership, the passiveness of citizens to hold their leaders accountable and a silent international community have combined to give African leaders an opportunity to wreck havoc on their countries and people (Mills, 2011). African leaders are, said President Goodluck Jonathan at the 2012 World Economic Forum in Addis Ababa, part of the problem of the continent as most of them place their ego above the interest of the people they lead (Ogbu, 2012). African leaders have actually been at the centre of persistent corruption, have aided illicit financial outflows and capital flight, frustrated local ingenuity, and led states as their personal property.

More than five decades after [independence], African states has [sic] remained in a vicious cycle of conflicts, stunted development and finally characterized by all indices of destructive governance; this time not as a result of colonial invasion but by the character of its leaders - power politics, endemic corruption, clientilism and politics of patronage (Mbah, 2013: p. 143) (emphasis added).

In line with this, some commentators have challenged radical scholars and sympathisers who have tended to externalise Africa's problems. They instead call for a balanced analysis and hold leaders accountable:

For decades, African radicals railed against colonial plunder, American economic imperialism, the avaricious propensities of Western banks, the predatory practices of multinational corporations, and the tight-fisted International Monetary Fund as the causes of Africa's economic crisis. For example, it was incessantly argued that Western banks, acting as monopolists, cornered credit markets and callously extracted exorbitant interest charges from destitute, problem-plagued African countries that could ill afford to pay them. ... But unethical practices by foreign banks and defects in the international economic system and other external factors alone are insufficient to explain Africa's economic crisis. Nor could foreign companies exploit African economies without the connivance or active encouragement of corrupt government officials (Ayittey, 1992: p. 234).

Of course such accounts help us understand why Africa remains entrenched in poverty for over fifty years of independence when there are examples of former colonies in Asia (India, South Korea, etc) which have made major strides in terms of development. Indeed, external factors are by no means adequate to explain Africa's underdevelopment. No one can say that Africa's loss of between $\$ 597$ billion and \$1.4 trillion in illicit financial flows in the past three decades (Sultan, 2014) is solely a result of external factors. Neither can we blame the international system and institutions for Africa's loss of about $\$ 150$ billion a year to corruption (Hanson, 2009). Similarly, external factors did not teach President Omar Bongo, former president of Gabon, to cling on to power for 42 years, appoint his son Ali as his minister of defence, his daughter Pascaline head of the presidency and his son in-law Paul Tongine the minister of foreign affairs (Mills, 2011: p. 230). For example, that the amount of money lost as a result of paying salaries to ghost workers in Tanzania increased from 178,066,130 shillings $(\$ 153,479)$ (Note 1) in 2007/2008 to $832,448,998$ shillings $(\$ 717,505)$ in 2012/2013 (National Audit Office, 2014, 2009) has nothing to do with external factors. The death of about a million Rwandans during the 1994 genocide, 300,000 Sudanese in the war in Darfur (Mills, 2011: pp. 4-5), and more than 5 million deaths in the Congo DRC since 1998 (Gettleman, 2010) cannot wholy be blamed on the international community or the international economic system. The international community and system, and colonial legacy may share some blame but the great responsibility lies with the Africans themselves. Certainly, as Mills argues 'Africa's failure is thus no mystry, but rather a rational choice by African leadership' (Mills, 2011: p. 232) 
aided by the passiveness of their citizens and the international community. And as one of the advocators of historical capitalist and imperialist exploitation of the periphery by the centre concludes,

Undoubtedly, African ruling classes were here maximally responsible for what was going to start the involution of the continent, particularly when they joined the neocolonial camp against the aspirations of their own people, whose weaknesses they exploited. The collusion between African ruling classes and the global strategies of imperialism is therefore, definitely, the ultimate cause of the failure (Amin, 2014: p. 32).

\section{Africa's Leadership Challenges: African and Global Responses}

The challenge of leadership and its subsequent impact on Africa's development and governance has generated concerted efforts, both from within and outside the continent, to try to address it. There has been a realisation that much of Africa's problems and challenges emanate from leadership and governance weaknesses; therefore addressing this is considered a prerequisite for development. The International Monetary Fund (IMF) for example, started paying more attention to governance issues which were believed to be significant in making the market work if they were addressed (Bolarinwa, 2013). As a result, IMF started to fund governance programmes in Africa, among others. Good governance became a condition to be fulfilled for African countries to receive grants and loans from the International Financial Institutions (IFIs). The main issue here was not achieving good governance for its own and the sake of Africans but for making sure that markets and capital would function properly in Africa. This was part of the reasons for why Africa was forced to liberalise its politics (democratisation) during the early 1990s.

The World Bank also emphasised the significance of good governance in resolving Africa's leadership and development challenges. It, for example, argued that better governance required political renewal which meant concerted efforts against corruption from the highest to the lowest levels and which could be done by setting a good example, by strengthening accountability, encouraging public debate, strengthening the press, empowering women and the poor (The World Bank, 1989). The result of this has been an increase in the number of non-governmental organisations and civil society organisations established and working in Africa. Such organisations are funded by, among others, the IFIs to champion good governance in Africa. For example, there are currently about 2,085 NGOs and CSOs (only those registered on the UN website) working in Africa on all areas of development (Note 2).

Moreover, governance, it is argued, ought to be improved for African countries and people to build real freedom and real development (Nyerere, 1998). He further reiterates that,

But to say this is very different from saying that because Africa is poor, Africans do not deserve good governance. This continent is not distinguished for its good governance of the peoples of Africa. But without good governance, we cannot eradicate poverty; for no corrupt government is interested in the eradication of poverty; on the contrary, and as we have seen in many parts of Africa and elsewhere, widespread corruption in high places breed poverty (Nyerere, 1998: para. 27).

On the other front, addressing leadership deficit in Africa has also taken a motivational approach which involves recognising and awarding the 'best' performing leaders as a means of motivating them to observe good governance ideals. The MO Ibrahim Foundation, for instance, established, in 2007, the Ibrahim Prize for Achievement in African Leadership with the aim of celebrating excellence in African leadership by awarding a prize to a deserving former Head of State or Government (http://www.moibrahimfoundation.org/ibrahim-prize/). The prize is awarded to former African Executive Head of State or Government who left office in the last three years, was democratically elected, served his/her constitutionally mandated term and demonstrated exceptional leadership. The award consists of a monetary prize totaling $\$ 5$ million over ten years and $\$ 200,000$ a year for life thereafter (http://www.moibrahimfoundation.org/ibrahim-prize/). Since its inaugural in 2007, only three former Heads of States (namely, President Pedro de Verona Rodrigues Pires of Cape Verde in 2011, Festus Gontebanye Mogae of Botswana in 2008, and Joaquim Alberto Chissano of Mozambique in 2007) have received a prize (Ibid.). The prize was not awarded in 2009, 2010, 2012 and 2013 because there was no one deemed qualified for the award (Straziuso, 2012; Tran, 2009), a reflection of how serious the challenge of leadership is in Africa.

Moreover, there have been some local initiatives by the former and current leaders to try to address the challenge. As indicated in the introduction above, a group of past and present African leaders established in 2004 the African Leadership Council to 'confront the continent's pathology of poor leadership with deeds as well as words' (Rotberg, 2004: para. 10). By this initiative, the leaders put in place a Code of African Leadership with 23 commandments, issued a Mombasa declaration to promote better leadership and pledged to train their successors on the art of good governance (Rotberg, 2004). At its establishment, the council included former President Sir Ketumile Masire of Botswana, former Nigerian Head of State General Yakubu Gowon, Vice President Moody Awori of Kenya, former Prime Minister Hage Geingob of Namibia, and other present and former prime ministers and cabinet ministers from Sierra Leone, Kenya, Malawi, and Uganda (Ibid.). As Rotberg (2004) opined, such a bold and African initiative was promising, dramatic and represented a 
step forward irrespective of whether or not it could curb the challenges.

Furthermore, several leadership academies have been established to train and prepare the young generation for later leadership responsibilities. A good example here is the African Leadership Academy. This was established in 2004 with a vision of transforming Africa by developing ethical and entrepreneurial leadership (The Master Card Foundation, 2014). The academy is based in Africa and admits the youth aged between 15 and 18 to its two year pre-university programmes designed to 'provide young leaders with the knowledge and inspiration they need to take action as agents of positive change on the African continent' (African Leadership Academy, 2014). The academy believes its young leaders have already started making an impact on the continent through, for example, the launch of 44 non- profit and for-profit enterprises since inception (http://www.africanleadershipacademy.org/).

While all these strategies may be relevant in addressing Africa's leadership and governance challenges, they fall short of the fact that they are disconnected from the continent's history, especially its pre-colonial history. Much of the focus has been on domesticating western based governance and leadership models as if Africa' past has nothing to offer on that regard. It is for this reason that this paper draws some lessons from pre-colonial Africa's governance and leadership systems for the current leadership challenges as explained hereunder.

\section{Pre-colonial Leadership and Governance and Their Relevance to 21st century Africa}

While much attention has been put on building good governance and leadership institutions in Africa modelled on Western/foreign concepts of leadership, less attention has been put on how Africa's past can provide good lessons and how its pre-colonial leaders can be good role models to $21^{\text {st }}$ century African leaders. The neglect of Africa's past leadership achievements and its lessons to today's Africa is understandable given that much of the development and governance thinking has been dominated by the Western models. Much of the knowledge about Africa has been produced by non-Africans and where Africans have tried to write about Africa from the perspective of Africans, this has been dismissed as nationalist historiography worth nothing other than trying to revive the dead past. In fact, there have been deliberate efforts to persuade Africans to forget their past and focus on the present and future trajectories as if Africa's development is disconnected from its past history (Obiyo, 2011). Even where some lessons are drawn from Africa's pre-colonial leadership, these tend to be regarded as only suitable to the conditions of the time and as having no relevance what so ever to the complex challenges of the $21^{\text {st }}$ century:

It is true that pre-colonial Africa is replete with examples of traditional leadership and governance that evolved over time, developing institutions and styles of leadership suited to the realities of the time. The debate continues also about whether in pre-colonial Africa there existed social and cultural norms, political structures, and processes, as well as philosophical underpinnings of governance, that could find relevance and applicability in modern Africa.... For instance, pre-colonial Africa comprised largely nonmonetary, tribe based economies. The kind of preparation needed to rule in such pre-colonial African economies had to be different from the realities of leadership skills needed for the African economies of the second half of the twentieth century. Political entities in pre-colonial Africa were mostly ethnically homogenous. The new leaders of Africa inherited, for the most part, an amalgam of diverse, sometimes antagonistic tribes that were forced into one geographic entity whose boundaries were decided by colonial powers in Berlin in 1884-85. ... addressing this challenge required a completely new set of leadership skills and governance systems for the newly independent nations (Mkapa, 2010: pp. 25-26).

Although there may be some truth, such views risk presenting a simplified version of the complex circumstances under which pre-colonial leadership and governance systems evolved. Similarly, such views only end up with a wrong conclusion as if there is nothing significant $21^{\text {st }}$ century leaders can take from pre-colonial leadership and governance systems. It is the argument of this paper that, although circumstances and conditions of pre-colonial and $21^{\text {st }}$ century Africa are different, there are lots of lessons current African leaders can learn for resolving the leadership challenges confronting the continent today. It is also argued that instead of current African leaders looking more to the East and West for leadership recipes, they should first of all dig into Africa's past leadership successes and challenges, build on these in combination with other relevant recipes for them to be able to resolve the challenges confronting the continent.

Pre-colonial Africa is replete with examples of successful and influential leaders who were capable of building kingdoms and empires and defending them, albeit not without challenges. There are also some examples of leaders who built their states through their participation in the notorious slave trade and slavery. Whatever the case, these leaders signified high level of thinking and planning so that they could take advantage of opportunities for their societal advancement. Going by the three major empires of West Africa- Ghana, Mali and Songhai- one finds that there are several lessons current African leaders can learn from the emperors of the time. This is because empire and kingdom building reflected a high level of sophistication of pre-colonial leadership and institutions (Falola \& Aderinto, 2010).

All these three empires rose, developed and became consolidated mainly because of their involvement and control over 
trading activities, the Trans Saharan Trade. Trade flourished in these empires not because they had crucial trade commodities- gold particularly, but because the leaders played a decisive role of creating enabling environment for trading activities and for foreign traders to come and trade with them. While the Trans Saharan Trade is most talked about, the empires and kingdoms also promoted intraregional trade which basically formed the basis for the later development of an interregional Trans Saharan Trade. Apart from the exchange of commodities, such trading activities were relevant as they provided a reliable source of revenue through taxation of all goods carried through the empires (Craig, Graham, Kagan, Ozment, \& Turner, 2012). Taxes, among other things, helped the emperors to provide the necessary public goods and services such as, for example, protecting trade routes against bandits who might rob traders (Ibid.). Leaders were equally important in creating conditions that made Muslim traders feel comfortable trading in the region, and also attracted foreign expertise, technology and knowledge which they made use of to develop their societies and their people. For example, on coming from Mecca, Mansa Musa brought many Muslim scholars, artists, scientists, and architects, and fostered the spread of Islam thus making Timbuktu become famous for its madrasas and libraries (Craig, Graham, Kagan, Ozment, \& Turner, 2012).

While trade was a very significant economic activity in all states of pre-colonial Africa, it was by no means the only sector on which the economy depended. In some states, efforts were made to diversify the economy by promoting other economic activities alongside trade. In the Mali empire, for example, alongside trading activities the people of Mali also practiced crop cultivation, livestock keeping, fishing, metal working (iron and gold), and cotton weaving (Craig, Graham, Kagan, Ozment, \& Turner, 2012).

All these point to the fact that current African leaders have many things to learn from the pre-colonial African leaders. Four issues that are critical for $21^{\text {st }}$ century Africa's development are emphasised here: revenue collection and spending, economic diversification, knowledge and expertise from outside, encouraging intraregional trade, and democratic governance.

First of all, collecting revenues and proper use of collected revenues remains one of the major challenges confronting Africa today. Revenue collection is very vital in that without it governments cannot perform their duties accordingly (Chijoriga, 2012). This is why pre-colonial African states took the issue of revenue collection very seriously and used whatever means was in their control to effect that. In the Ghana Empire, for example, the king collected tax from all traders coming into and leaving Ghana and used the revenues to strengthen protection of merchants and provide other relevant services (Newsflash, 2007). African countries have continued to struggle with the collection and use of revenues. Revenue collection continues to be beset by widespread tax evasion and tax avoidance by corporations and wealthy elites (Christensen, no date). Contrary to pre-colonial states where no one was exempted from paying taxes, African countries have not been taxing all people and corporations due to overgenerous tax incentives designed to attract investors and make the countries competitive. For example, it is reported that four East African countries, Kenya, Rwanda, Tanzania and Uganda, are losing up to US $\$ 2.8$ billion annually from tax incentives and exemptions (Tax Justice Network-Africa \& ActionAid International, 2012). Of these countries, Tanzania has the highest tax exemption to GDP ratio in East Africa (Kitillya, 2011). Its tax exemption to GDP ratio amounted to 4.3\% of GDP in the 2011/12 financial year and increased in value from Tanzanian shillings (Tshs.) 680 million in 2009/10 to Tshs. 1.8 trillion in 2011/12 ( representing an increase of the proportion of tax exemptions to actaul collected revenues from 15\% in 2009/10 to 27\% in 2011/12) (Policy Forum, 2013: pp. 1-2). Unless African leaders take tax/revenue collection and spending seriously, there can be no guarantee that development challenges will be resolved.

The second lesson concerns the importance of economic diversification. Although the economies of the empires of Ghana, Mali and Songhai were based mainly on trade, several other economic activities were undertaken and encouraged, thus guaranteeing economic prosperiy to the empires and the people. In the empire of Songhai, for instance, apart from trade, other economic activities that were undertaken were farming, craft making, and fishing (Conrad, 2005). Furthermore, the empire of Mali is said to have prospered and avoided the famine that stroke Ghana mainly because it encouraged expanded food production, animal keeping, fishing, metal working (iron and gold), cotton weaving, and trade (Craig, Graham, Kagan, Ozment, \& Turner, 2012). All these made the empires expand economically as it became possible for them to feed themselves and garner a range of commodities for exchange. While all African countries have economies characterised by different economic activities, some, especially the resource rich countries, are heavily dependent on one sector. Nigeria for example, has been heavily dependent on its oil sector to the extent of negatively affecting its once vibrant agricultural sector (Akpan, 2012). Similarly, Angola has been heavily dependent on oil extraction to the extent that all other economic sectors have stagnated or declined since the 1970s hence leaving it 'overwhelmingly dependent on oil revenue, which has been used to finance imports, consumer goods and equipment for the oil industry' (Andre, 2010: pp. 5-6). For example, of the US\$63,918 millions received from the country's exports in 2008, US\$61,666 million (over 96\%) was accounted for by crude oil exports (Andre, 2010: p. 6). Such a situation is very dangerous as it risks the countries running into recession when prices of their exports fall down. It is significant, 
therefore, for African countries to look back into history and learn from pre-colonial economies and diversify their economies away from dependence on natural resources.

Third is the use of knowledge and expertise from outside. The $21^{\text {st }}$ century world is very rich in knowledge and skills to the extent that countries lacking in some skills and expertise can easily learn and adapt them from where they are readily available. This is what the leaders of the Mali empire did to put Mali on the map of the world. After attending his pilgrimage, Mansa Musa is said to have brought many Muslim scholars, artists, scientists, and architects back to Mali and made use of their knowledge and expertise for the expansion and administration of the empire (Craig, Graham, Kagan, Ozment, \& Turner, 2012; Goodwin, 1957). He similarly, fostered the spread of Islam and its associated education institutions, and used it as a unifying force in the empire the consequence of which was increased foreign traders inflows into Mali and the expansion of trading activities (Craig, Graham, Kagan, Ozment, \& Turner, 2012). 21 ${ }^{\text {st }}$ century African leaders should definitely learn from the expertise and skills of other countries and strive to make use of them for the advancement of the people of their countries, not otherwise.

One of Africa's economic challenges in the $21^{\text {st }}$ century is that there is little intra-African trade. Much of the trade in Africa has been between African countries and the Europeans, Americans and the emerging economies. The share of intra-African trade has declined from $22.4 \%$ in 1997 to around 12\% in 2011 (UNCTAD 2013, in Zonke, 2014: p. 89). It is argued that trading within Africa is more costly than trading outside Africa given the fact that many African countries are beset by very poor infrastructure, and destructive tariffs, among others (Zonke, 2014). For so long, African countries have been urged to develop strong trade relations between and among them as a means of shielding themseleves from the vagaries of the world commodity markets (Zonke, 2014; Moyo, 2009) though this is yet to be heeded to. Looking back into history, pre-colonial African societies appear to have involved themselves in intraregional trade long before they started trading with the external world. In West Africa when the Portuguese arrived in 1471, they found Ghana already trading with neighbouring coastal societies (Perbi, 2001). Moreover,

All the West African states along the Atlantic coast were linked by a southern trade route covering modern Senegal to modern Nigeria. Ghana, again because of its wealth in gold, exchanged gold for slaves, beads, cotton, cloth and palm oil from the Benin state in modern Nigeria. From Dahomey and Ivory Coast, Ghana exchanged gold for the famous A quaqua@ [sic] cloth. Shama on the Ghana coast was the entrepot of trade (Perbi, 2001: p. 4).

Though international trade became significant later, the importance of intraregional trade remained intact and was the foundation on which international long distance trade was built. Given the limited intra-African trade, can't African leaders today learn from this past experience?

Equally important is the fact that pre-colonial African leaders were never autocratic. There were serious democratic elements in traditional Africa which could be said to be somehow related to present day democratic ideals (Chimakonam, Agu, \& Agbo, 2014). Although in all cases the king or emperor wielded enormous powers, such powers were usually balanced and checked as citizens were directly and indirectly involved in the day to day governance of their empires (Ayittey, 1992). Pre-colonial African leaders/kings were therefore bound to serve their people, and observe customs and traditions short of which a king would be removed by the same people he was leading provided that certain conditions were fulfilled:

First, only those who enstooled him could destool him. Thus, only members of the ruler's council could make formal statements of grievances and start the procedures for destoolment. Council members normally acted in response to public opinion from the villages, districts, or the state as a whole. If the council failed to act, the people would either move elsewhere (vote with their feet) or rise up in open rebellion. Second, potential successors to the stool were not allowed to lead destoolment proceedings. Among the Akan states of Ghana, members of the royal family were debarred from these procedures. Enstoolment and destoolment were the right of the people (Ayittey, 1992: p. 61).

In all these, the principle of natural justice was upheld as the king was usually given an opportunity to defend himself before he could be destooled. As such, the kings/chiefs/emperors were not rulers; they were leaders (Ayittey, 1992). All this helped to limit the powers of kings by keeping them in balance and checks and ensuring that democratic principles were upheld.

One implication and lesson from this is that democratic governance in Africa predates the western based governance models. It similarly means that current African leaders should not take trouble trying to domesticate Western based democratisation as they can learn more from what African leaders of the pre-colonial period did. As some scholars argue,

the traditional pre-colonial Africa had a political order that was to some extent democratic. The difference is 
that instead of say majority principle, the traditional Africa operated with consensus and unanimity principles. This creates an orientation of all-inclusion. It then means that to obtain a viable democratic alternative that would work in Africa some restructuring needs be done on the current Western-styled liberal democracy by adapting and modernizing Africa's traditional democratic system (Chimakonam, Agu, \& Agbo, 2014: p. 141).

Significant to remember is the fact that power does not belong to leaders but to people and that the role of leaders is not to rule but lead their people into prosperity, freedom, equality and development. Moreover, the impunities and atrocities committed by current leaders should not be tolerated; leaders ought to learn to respect and become responsive to their citizens' needs and aspirations instead of just becoming custodians of the corporate world interests. They therefore have to lead their citizens and govern with them; they should not try to impose decisions on them nor think that they know better than their citizens (Smit, 2010). Only by realising and doing this can their leadership be legitimate, and conflicts and development challenges addressed.

Important to $21^{\text {st }}$ century Africa is the need to create strong and lasting governance and leadership institutions that can outlive the lifespan/service term of leaders. This is very significant because many African countries have been lacking coherent, strong and long term institutions that can withstand any external and/or internal challenges. The famous West African empires grew and expanded mainly because leaders were able to expand and protect them both economically and territorially. The leaders played key role in controlling trade through their empires from which they garnered much of the wealth they used to strengthen their empires (Konneh, 1998). However, the strong leadership and governance factors that had helped the empires to expand and consolidate themselves soon proved weak as the empires collapsed one after another. This collapse had much to do with the death of strong leaders, conquests, inability to maintain control over expanding territories, and loss of control over trading activities (Iliffe, 1995; Levtzion, 1963; Decraen, 1962; Goodwin, 1957). Current African leaders need to pick this as a challenge and opportunity for them to endeavour to create long lasting leadership and institutions that can outlive their lives. This is because '[e]nsuring that in the event of a problem with a sitting President, a country will continue to function efficiently and effectively creates tremendous value for citizens' (Mawere, 2009). Despite this potential, leadership succession in Africa remains a daunting challenge. Many good leaders have failed to create systems that would ensure their countries function properly long after they are gone or when they are no longer in power. In Tanzania, for example, it is very common to hear citizens and leaders alike lamenting on why what the first President, Mwalimu Julius Kambarage Nyerere, struggled to achieve have all been lost. This reflects the failure of Nyerere's regime to create leadership and governance institutions that would have ensured that the good things it achieved were preserved and passed on to other leadership regimes. But as Mawere (2009: para. 14) argues, 'many African Presidents genuinely believe that the continent has no capacity to produce leaders like them. In fact, they are encouraged everyday to believe that they are the messiahs of the continent and any change will interrupt progress.' The collapse of the great pre-colonial African empires should indeed awaken $21^{\text {st }}$ century leaders of Africa to the need and significance of creating leadership and governance institutions that can outlive them and ensure that what they strive for is passed on from generation to generation.

\section{Conclusion}

Africa continues to face a host of challenges as it struggles to bring about inclusive, equitable and sustainable development. Although several theories have been advanced to explain why Africa remains poor for over fifty years of independence, this paper has argued that Africa's poverty has more to do with its internal weaknesses, notably its bad leadership than external forces. This, however, is not to disregard the role of external factors. Far from it. External factors have significantly altered Africa's path to inclusive and sustainable socio-economic development but this has generally been because of the enabling conditions created by the African leaders. To argue that Africa's problems are a result of external forces is to risk passivising Africans, seeing them as passive recipients of changes and challenges. African leaders supported by the passiveness of the citizens and the weaknesses in the global governance institutions have wrecked havoc on the continent and its people through poorly thought out ideologies and policies, corruption, illicit capital flights, dubious agreements with multinational and transnational corporations, abuse of human rights, etc.

While several efforts have been made to address Africa's leadership and governance challenges, these have generally been externally driven and informed. The strategies, it has been argued, have been completely detached from the continent's rich pre-colonial history as if there was nothing significant to be learned. This paper has tried to address this anomaly by highlighting some lessons that can be learnt from the leaders and governance systems of pre-colonial Africa. It has been argued that although leaders and governance systems suited the material conditions of the time, much of what the leaders did are still relevant today. Such issues as revenue/tax collection, learning and making use of foreign knowledge, skills and expertise, democratic governance, economic diversification, and encouraging intra-African trade continue to be relevant today. And on these, Africa has a lot to learn from its pre-colonial history. 


\section{References}

Afegbua, S. I., \& Adejuwon, K. D. (2012). The Challenges of Leadership and Governance in Africa. International Journal of Academic Research in Business and Social Sciences, 2(9), 141-157.

African Leadership Academy. (2014). World Class Curriculum. Retrieved August 11, 2014, from http://www.africanleadershipacademy.org/building-foundation/world-class-curriculum

Akpan, N. S. (2012). From Agriculture to Petroleum Oil Production: What Has Changed about Nigeria's Rural Development? International Journal of Developing Societies, 1(3), 97-106.

Amin, S. (1977). Imperialism and Unequal Development. New York and London: Monthly Review Press.

Amin, S. (2011). Global History: A View From the South. Cape Town, Dakar, Nairobi and Oxford: Pambazuka Press.

Amin, S. (2014). Understanding the Political Economy of Contemporary Africa. Africa Development, XXXIX(1), 15-36.

Andre, G. (2010). The Management Of The Angolan Oil Revenues: Are There Any Chances To Change Course Of The Resource Curse"? Retrieved September 1, 2014, from http://www.google.co.tz/url?sa=t\&rct=j\&q=\&esrc=s\&source=web\&cd=4\&cad=rja\&uact=8\&ved=0CEYQFjAD\& url=http $\% 3 \mathrm{~A} \% 2 \mathrm{~F} \% 2 \mathrm{Fwww}$.eisourcebook.org\%2Fcms\%2FMarch_2013\%2FAngola\%2520Oil\%2520Revenues $\% 2$ 520and\%2520Resource\%2520Curse.pdf\&ei=WJADVKmzLqaO7Qbl0IHICw\&usg=AFQjCNGgP

Ayittey, G. B. (1992). Africa Betrayed. New York: St. Martin's Press.

Ayittey, G. B. (1999). Africa in Chaos. New York: St. Martin's Griffin.

Bolarinwa, J. O. (2013). Good Governance and Economic Development: The Challenges of Democratic Sustainability in Nigeria. African Journal of Governance and Development, 2(2), 4-17.

Bond, P. (2006). Looting Africa: The Economics of Exploitation. London and New York: Zed Books.

Calderisi, R. (2007). The Trouble with Africa: Why Foreign Aid Isn't Working. New Haven and London: Yale University Press.

Chijoriga, M. M. (2012). New Areas for Enhancement of Revenue Collection and Broadening Tax Base of the Country. Paper Presented at the Consultative Forum Organised by the CAG, 2nd March. Retrieved August 15, 2014, from nao.go.tz/?wpfb_dl=48

Chimakonam, J. O., Agu, S. N., \& Agbo, J. N. (2014). The Nemesis of Individualistic Ontology in Globalization and the Practice of Liberal Democracy in Post-Colonial Africa. The Journal of Pan African Studies, 7(4), 137-155.

Christensen, J. (no date). Africa's Lost Tax Revenue, Lost Development Opportunities. Retrieved August 31, 2014, from http://concernedafricascholars.org/bulletin/issue87/christensen/

Conrad, D. (2005). Empires of Medieval West Africa: Ghana, Mali, and Songhay. New York: Facts on File, Inc.

Craig, A. M., Graham, W. A., Kagan, D., Ozment, S., \& Turner, F. M. (2012). The Heritage of World Civilizations, Combined Volume, Brief Fifth Edition. Peachpit Press.

Decraen, M. (1962). Le Mali Médiéval / Mediaeval Mali. Civilisations, 12(2), 250-258.

Falola, T., \& Aderinto, S. (2010). Nigeria, Nationalism, and Writing History. Rochester: University of Rochester Press.

Gettleman, J. (2010, February 22). Africa's Forever Wars: Why the Continent's Conflicts Never End. Retrieved August 25, 2014, from Foreign Policy: http://www.foreignpolicy.com/articles/2010/02/22/africas_forever_wars

Goodwin, A. J. (1957). The Medieval Empire of Ghana. South African Archaeological Society, 12(47), $108-112$. http://dx.doi.org/10.2307/3886971

Hanson, S. (2009, August 6). Corruption in Sub-Saharan Africa. Retrieved August 24, 2014, from Council on Foreign Relations: http://www.cfr.org/africa-sub-saharan/corruption-sub-saharan-africa/p19984

Heleta, S. (2007). African Stagnation and Underdevelopment. Retrieved from http://www.google.co.tz/url?sa=t\&rct=j\&q=\&esrc=s\&source=web\&cd=4\&cad=rja\&uact=8\&ved=0CDoQFjAD\& url=http $\% 3 \mathrm{~A} \% 2 \mathrm{~F} \% 2 \mathrm{Fsavoheleta.com} \% 2 \mathrm{Fwp}-\mathrm{content} \% 2 \mathrm{Fuploads} \% 2 \mathrm{~F} 2013 \% 2 \mathrm{~F} 07 \% 2 \mathrm{FAfrican}$ _Stagnation_and_ Underdevelopment_Savo_Heleta_2007.pdf\&ei=82X4U4f7L4Kq0QWDp4GgDg\&usg=A

Iliffe, J. (1995). Africans: The History of a Continent. Cambridge: Cambridge University Press.

Kauzya, J.-M., \& Balogun, J. (2005). Governance and Public Administration Reforms and Innovations in African Countries: A Focus on Achievements, Setbacks and Future Directions. Retrieved from unpan1.un.org/intradoc/groups/.../unpan019929.pdf 
Kitillya, H. M. (2011). Tax Administration Reforms in Tanzania: Experiences and Challenges. Paper Presented at the Conference on Revenue Mobilisation in Developing Countries, IMF - Fiscal Affairs Department, Washington D.C., 17-19 April. Retrieved August 20, 2014, from https://www.imf.org/external/np/seminars/eng/.../revenue/pdf/kitillya.pdf

Konneh, A. (1998). Guimba the Tyrant [Guimba, un tyrant une époque] by Idrissa Ouedraogo; Cheick Oumar Sissoko. The American Historical Review, 103(5), 1737-1738. http://dx.doi.org/10.2307/2650170

Levtzion, N. (1963). The Thirteenth- and Fourteenth-Century Kings of Mali. The Journal of African History, 4(3), 341-353. http://dx.doi.org/10.1017/S002185370000428X

Mawere, M. D. (2009, December 11). Trust and succession politics in Africa. Retrieved August 22, 2014, from http://www.newzimbabwe.com/pages/mawere73.16345.html

Mbah, C. E. (2013). Leadership Question and Development Crises: The 21st Century Challenges in Africa and Quest for Change. Journal of Sustainable Development in Africa, 15(2), 142-153.

Mills, G. (2010, December 6). Why Is Africa Poor? Development Policy Briefing Paper No. 6. Retrieved from www.cato.org/pubs/dbp/dbp6.pdf

Mills, G. (2011). Why Africa is Poor and What Africans can do About it. Johannesburg: Penguin Books.

Mkapa, B. W. (2010). Leadership for Growth, Development and Poverty Reduction: An African Viewpoint and Experience. In D. Brady, \& M. Spence, Leadership and Growth (pp. 19-79). Washigton DC: The International Bank for Reconstruction and Development /The World Bank.

Moyo, D. (2009). Dead Aid: Why Aid Is Not Working and How There Is a Better Way for Africa. London: Allen Lane.

National Audit Office . (2014). Annual General Report of the Controller and Auditor General on the Financial Statements of the Local Government Authorities For the Financial Year Ended 30th June, 2013. Retrieved June 15, 2014, from http://nao.go.tz/?wpfb_dl=113

National Audit Office. (2009). Annual General Report of the Controller and Auditor General of the Financial Statements of the Local Government Authorities for the Financial Year 2007/2008. Retrieved June 5, 2014, from http://nao.go.tz/?wpfb_dl=18

Newsflash. (2007). Ghana, Mali and Songhai Empires. Retrieved August 31, 2014, from www.csep.org.uk/pdf/newsflash_empires.pdf

Nkrumah, K. (1965). Neo-colonialism: The Last Stage of Imperialism. London: Thomas Nelson \& Sons Ltd.

Nyerere, J. K. (1998, October 13). Good Governance for Africa. Retrieved August 30, 2014, from Marxism in Africa: https://www.marxists.org/subject/africa/nyerere/1998/10/13.htm

Obiyo, C. (2011). Should African Nations Forgive and Forget? Retrieved September 1, 2014, from http://myafricanplan.com/2011/01/should-african-nations-forgive-and-forget/

Ogbu, A. (2012, May 11). Underdevelopment: Jonathan Chides African Leaders. Retrieved August 24, 2014, from This Day Live: http://www.thisdaylive.com/articles/underdevelopment-jonathan-chides-african-leaders/115585/

Perbi, A. (2001). Slavery and Slave Trade in Pre-colonial Africa. Retrieved August 20, 2014, from www.latinamericanstudies.org/slavery/perbi.pdf

Policy Forum. (2013). Tanzania and the problem of Tax Exemptions. Poliy Brief 3:2013. Retrieved August 22, 2014, from www.policyforum-tz.org/sites/default/files/Taxpolicybrief.pdf

Rodney, W. (1973). How Europe Underdeveloped Africa. Dar es Salaam: Tanzania Publishing House.

Rotberg, R. I. (2004). Strengthening African Leadership. Retrieved from Foreign Affairs: http://www.foreignaffairs.com/articles/59914/robert-i-rotberg/strengthening-african-leadership http://dx.doi.org/10.2307/20034043

Smit, E. (2010). Perceptions on Leadership in Africa. Retrieved September 1, 2014, from www.usb.ac.za/Media/News/eon_smit.pdf

Straziuso, J. (2012, October 15). Mo Ibrahim Prize 2012: No African Leader Qualifies For \$5m Award, Again. Retrieved August 22, 2014, from The World Post:

http://www.huffingtonpost.com/2012/10/15/mo-ibrahim-prize-2012-no-winner_n_1966535.html 
Sultan, M. (2014, April 21). How Illicit Financial Flows Drain African Economies. Retrieved August 24, 2014, from Open Society Foundations: http://www.opensocietyfoundations.org/voices/how-illicit-financial-flows-drain-african-economies

Tax Justice Network-Africa \& ActionAid International. (2012). Tax competition in East Africa: A Race to the Bottom? Retrieved August 31, 2014, from http://www.actionaid.org/sites/files/actionaid/eac_report.pdf

The Master Card Foundation. (2014). African Leadership Academy. Retrieved August 11, 2014, from http://www.mastercardfdn.org/Projects/african-leadership-academy-ala

The World Bank. (1989). From crisis to sustainable growth - sub Saharan Africa : a long-term perspective study. Retrieved August 30, 2014, from

http://documents.worldbank.org/curated/en/1989/11/439705/crisis-sustainable-growth-sub-saharan-africa-long-ter m-perspective-study

Tran, M. (2009, October 19). Mo Ibrahim prize for African leadership will not be awarded this year. Retrieved August 22, 2014, from The Guardian:

http://www.theguardian.com/world/2009/oct/19/mo-ibrahim-african-leadership-prize

Zonke, S. (2014, August). Where are we with Intra-African Trade? Sawubona, 88-90.

\section{(c) $)$ EY}

This work is licensed under a Creative Commons Attribution 3.0 License. 